\title{
Incidence of Hypophosphatemia after Ferric Carboxymaltose Treatment: Single Center Experience
}

\author{
Demir Karboksimaltoz Tedavisi Sonrası Hipofosfatemi Sıklığl: Tek Merkez Deneyimi
}

\author{
(D) Esra TERZI DEMIRSOY
}

University of Health Sciences Turkey, Derince Training and Research Hospital, Clinic of Hematology, Kocaeli, Turkey

\begin{abstract}
Aim: The aim of this study was to evaluate the incidence of hypophosphatemia after ferric carboxymaltose (FCM) infusion and the factors affecting hypophosphatemia.

Materials and Methods: Ninety-two patients who received FCM treatment for iron deficiency anemia (IDA) were included in the study. Phosphorus, calcium, magnesium, 25-hydroxy vitamin D, and parathyroid hormone levels before and after FCM infusion were obtained from the medical records. Hypophosphatemia was defined as serum phosphorus level of $<2.5 \mathrm{mg} / \mathrm{dL}$ and severe hypophosphatemia as $<1 \mathrm{mg} / \mathrm{dL}$. The cut-off value for baseline phosphorus in predicting hypophosphatemia was detected as $3.4 \mathrm{mg} / \mathrm{mL}$ with the ROC analysis.

Results: Seventy-seven of the patients were women. The mean age was $47.5 \pm 15.5$ (18-85) years. Thirty of the patients (32.6\%) were given 500 $\mathrm{mg}$ iron as FCM and 62 patients (67.4\%) were given $1000 \mathrm{mg}$ iron as FCM. The level of serum phosphorus measured 10-14 days after FCM was determined lower than the baseline level $(2.22 \pm 0.57 \mathrm{mg} / \mathrm{dL}$ vs $3.34 \pm 0.39 \mathrm{mg} / \mathrm{dL}, \mathrm{p}<0.000)$. Hypophosphatemia was observed in 62 patients $(67.4 \%)$ after FCM infusion. Severe hypophosphatemia was seen in only 2 patients (2.1\%). Patients given a dose of $1000 \mathrm{mg}$ FCM had a higher incidence of hypophosphatemia compared to those given $500 \mathrm{mg}$ FCM (75.8\% vs 50\%, p=0.013). Baseline phosphorus level of $3.4 \mathrm{mg} / \mathrm{dL}$ was associated with an increased risk of developing hypophosphatemia with an odds ratio of 9.2 ( $p=0.001 ; 95 \%$ confidence interval: $3.41-25.21)$. On logistic regression analysis, it was found that baseline phosphorus level and a dose of $1000 \mathrm{mg}$ FCM were independent risk factors for the development of hypophosphatemia.

Conclusion: The incidence of hypophosphatemia due to FCM in our study was consistent with the literature. When FCM treatment is given to patients with IDA, the patients should be evaluated according to their baseline phosphorus level, the dose of FCM and frequency of administration, and it should be kept in mind to follow the phosphorus level in patients with risk for hypophosphatemia.
\end{abstract}

Keywords: Ferric carboxymaltose, iron deficiency anemia, hypophosphatemia

\section{ÖZ}

Amaç: Demir karboksimaltoz (DKM) infüzyonu sonrası hipofosfatemi sıklığını ve hipofosfatemiye etki eden faktörleri değerlendirmek amaçlanmıştır. Gereç ve Yöntem: Demir eksikliği anemisi (DEA) nedeniyle DKM tedavisi alan 92 hasta çalışmaya alındı. DKM öncesi ve sonrası fosfor, kalsiyum, magnezyum, 25-hidroksi vitamin D, parathormon seviyeleri dosya bilgilerinden kaydedildi. Hipofosfatemi serum fosfor düzeyinin $<2,5 \mathrm{mg} / \mathrm{dL}$ olması, ağır hipofosfatemi de $<1 \mathrm{mg} / \mathrm{dL}$ olması şeklinde tanımlandı. Hipofosfatemiyi öngörmede bazal fosfor düzeyi için cut-off değeri ROC analizi ile 3,4 $\mathrm{mg} / \mathrm{dL}$ olarak saptandı.

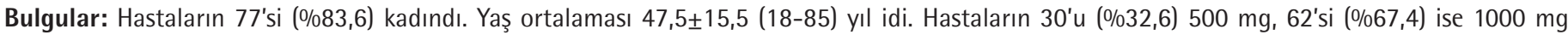
dozunda DKM tedavisi aldı. DKM tedavisi sonrası 10.-14. gün bakılan serum fosfor düzeyi bazal değerine göre düşük bulundu $(2,22 \pm 0,57 \mathrm{mg} / \mathrm{dL}$ vs $3,34 \pm 0,39 \mathrm{mg} / \mathrm{dL}, \mathrm{p}<0,000)$. Altmış iki hastada $(\% 67,4)$ tedavi sonrası hipofosfatemi gözlendi. Ağır hipofosfatemi sadece iki hastada $(\% 2,1)$ görüldü. 1000 mg DKM alanlarda, 500 mg DKM alanlarla karşılaştırıldığında hipofosfatemi daha sıktı (\%75,8 vs \%50, p=0,013). Bazal fosfor düzeyinin $\leq 3,4$

Address for Correspondence: Esra TERZi DEMIRSOY MD, University of Health Sciences Turkey, Derince Training and Research Hospital, Clinic of Hematology, Kocaeli, Turkey Phone: +90 5056565442 E-mail: esraterzi@gmail.com ORCID ID: orcid.org/0000-0001-7083-9379

Received: 01.02.2021 Accepted: 20.04.2021 
mg/dL olması 9,2 bir olasılık oranıyla hipofosfatemi geliştirme riskinde artış ile ilişkili bulundu [(p=0,001, \%095 güven aralığı: 3,41-25,21). Lojistik regresyon analizinde ise bazal fosfor düzeyi ve 1000 mg DKM dozunun hipofosfatemi gelişimi için bağımsız risk faktörleri olduğu tespit edildi.

Sonuç: Çalışmamızda DKM'ye bağlı hipofosfatemi sıklığı literatür ile uyumlu idi. DEA olan hastalara DKM tedavisi verilirken bazal fosfor düzeyi, DKM dozu ve DKM uygulama sıklığına göre hastalar değerlendirilmeli; hipofosfatemi açısından riskli hastalarda fosfor seviyesinin takip edilmesi akılda tutulmalıdır.

Anahtar Kelimeler: Demir karboksimaltoz, demir eksikliği anemisi, hipofosfatemi

\section{INTRODUCTION}

Iron deficiency is the most common nutritional disorder in the world. It is estimated that the majority of pre-school children and pregnant women in developing countries and at least 30$40 \%$ in developed countries have iron deficiency'. According to the 2011 World Health Organization (WHO) data, the estimated prevalence of anemia in Turkey is $28.2 \%$ in pregnant women and $29 \%$ in women of reproductive age (15-49 years) ${ }^{2}$.

Oral iron preparations are used in the first-line treatment of iron deficiency anemia (IDA) because they are inexpensive and easy to use. The most common side effects of this treatment are nausea, bloating, abdominal pain, diarrhea and constipation ${ }^{3}$. About half of the patients cannot complete their treatment for this reason, and this leads to treatment failure ${ }^{4}$. Parenteral iron therapy is used in cases of intolerance to oral iron therapy or when this therapy is not effective. Iron dextran is a first generation intravenous (iv) agent, and it is the iv agent with the highest risk of anaphylaxis. Second generation agents are ferrous gluconate and iron sucrose. Although anaphylaxis is seen at a lower rate than iron dextran, these agents cannot be administered at high doses at once. Due to administration and anaphylaxis problems, new generation iron compounds have been developed in recent years that allow high amounts of iron to be given with a single dose infusion. Ferric carboxymaltose (FCM), which we use frequently in our clinical practice, is also in this group 5 .

Transient hypophosphatemia has been described in the early period in patients receiving iv iron therapy. Hypophosphatemia is more common and longer lasting in FCM compared to other agents ${ }^{6-8}$. It is thought that the transient increase in serum levels of fibroblast growth factor-23 (FGF-23), which stimulates the renal excretion of phosphorus, causes hypophosphatemia ${ }^{8}$. In this study, we aimed to examine the incidence of hypophosphatemia and the factors affecting hypophosphatemia in patients receiving FCM treatment for IDA.

\section{MATERIALS AND METHODS}

Patients who received FCM with the diagnosis of IDA in our hematology outpatient clinic between October 2016 and January 2019 were retrospectively screened. Patients whose serum phosphorus levels were reached before and after DCM treatment were included in the study. Exclusion criteria were determined as; being younger than 18 years old, pregnancy, chronic kidney disease, parathyroid disease, presence of osteoporosis, hematological or non-hematological active malignancies, receiving chemotherapy, using active vitamin $D$, having erythrocyte transfusion in the 1 month before the treatment and receiving oral or parenteral iron therapy.

Ninety-two patients who met the criteria were included in the study. According to the WHO classification, anemia was defined as hemoglobin $(\mathrm{Hb})<12 \mathrm{~g} / \mathrm{dL}$ in women and $<13 \mathrm{~g} / \mathrm{dL}$ in men ${ }^{9}$. If the ferritin value was $<30 \mathrm{ng} / \mathrm{mL}$, it was accepted as IDA ${ }^{10}$. Before FCM treatment and between 10-14 days of treatment, complete blood count, serum iron, total iron binding capacity (TIBC), ferritin, phosphorus, calcium, magnesium, 25-hydroxy vitamin D (25-OH Vit D) and parathormone (PTH) values were recorded. Transferrin saturation (TS) was calculated using the formula (serum iron level/TIBC)x100. Hypophosphatemia was defined as serum phosphorus level being $<2.5 \mathrm{mg} / \mathrm{dL}$, and severe hypophosphatemia being $<1 \mathrm{mg} / \mathrm{dL}$.

Etiological diagnoses were coded using the $10^{\text {th }}$ revision of higher-level classification of the International Statistical Classification of Diseases and Associated Health Problems (International Classification of Diseases-10) ${ }^{11}$. Total iron needs of the patients were calculated according to the doses recommended by the brief product information of FCM (Ferinject ${ }^{\oplus}$ vial 500 mg, Abdi Ibrahim-Vifor Pharma). Patients with a total iron need of 500-1000 mg were given $500 \mathrm{mg}$ FCM for the first time, and those with a total iron need of more than $1000 \mathrm{mg}$ were given $1000 \mathrm{mg}$ of FCM for the first time.

Ethics committee approval was obtained by the Üniversity of Health Sicences Turkey, Kocaeli Derince Training and Research Hospital Clinical Research Ethics Committee with the protocol number 2020/82 dated 25.06.2020.

\section{Statistical Analysis}

The data were classified and analyzed using the IBM Statistical Package for the Social Sciences version 20 (SPSS Inc., Chicago, IL, USA) program. The Shapiro-Wilk test was used to evaluate whether the distribution of continuous variables was normal. Normally distributed continuous variables were given as mean \pm standard deviation. Continuous variables that did not show normal distribution were expressed as median- 
interquartile range. Percent and number values were given for categorical variables. Paired-samples t-test was used to compare two dependent groups for normally distributed variables and Wilcoxon signed rank test was used for nonnormally distributed variables. In the comparison of two independent groups, Independent-samples T test was used for normally distributed variables and Mann-Whitney $U$ test was used for non-normally distributed variables. Pearson chi-square test and Fisher's Exact test were used to evaluate categorical data according to groups. Diagnostic screening tests and ROC analysis were used to calculate the basal phosphorus level cutoff point to determine the development of hypophosphatemia. The cut-off point for basal phosphorus level was determined as $\leq 3.4 \mathrm{mg} / \mathrm{dL}$ by ROC analysis. Logistic regression analysis was used for multivariate analysis of risk factors affecting the development of hypophosphatemia. A p value less than 0.05 was accepted as statistical significance.

\section{RESULTS}

Ninety-two patients were included in the study. Of these, 77 (83.6\%) were female and 15 (16.4\%) were male. The mean age was $47.5 \pm 15.5(18-85)$ years. All patients received $500 \mathrm{mg}$ $(32.6 \%)$ or $1000 \mathrm{mg}(67.4 \%)$ FCM treatment at one time. When evaluated according to etiology, abnormal uterine bleeding was the most common cause in 51 patients (55.4\%). Digestive system diseases were seen in 28 patients (30.4\%), circulatory system diseases were seen in 7 patients $(7.6 \%)$, and malignant diseases were seen in 6 patients (6.5\%). All of our patients with anemia due to genitourinary system diseases were women and as expected, there were abnormal uterine bleedings such as menorrhagia, metrorrhagia, menometrorrhagia and hypermenorrhea. Of our patients with anemia due to digestive system diseases, 4 had a history of Billroth surgery (due to gastric ulcer), 1 had bariatric surgery, 4 had celiac disease, and 1 had ulcerative colitis. Erosive gastropathy was also detected in the gastroscopic examination of the remaining 18 patients. Circulatory system diseases included coronary artery disease and heart failure. Of the 6 patients with malignancy, 2 had gastric adenocarcinoma, 2 had gastric lymphoma, 1 had esophageal and 1 had colon cancer. Hb, hematocrit, TS, ferritin levels measured between 10-14 days after FCM treatment were higher than before treatment and serum phosphorus level was found to be lower (Table 1).

Hypophosphatemia was observed between 10-14 days after FCM in 62 patients (67.4\%). Severe hypophosphatemia was seen in only 2 patients (2.1\%), and 2 of them were given $1000 \mathrm{mg}$ FCM. $75.8 \%$ of the patients who developed hypophosphatemia received $1000 \mathrm{mg}$ FCM. This rate was 50\% $(\mathrm{p}=0.013)$ in the group that did not develop hypophosphatemia. The comparison of demographic and baseline laboratory characteristics of groups with and without hypophosphatemia is shown in Table 2.

The cut-off point for basal phosphorus level was determined as $\leq 3.4 \mathrm{mg} / \mathrm{dL}$ by ROC analysis. A basal phosphorus level of $\leq 3.4 \mathrm{mg} / \mathrm{dL}$ was associated with an increased risk of developing hypophosphatemia with a probability ratio of $9.2[p=0.001$, Odds ratio: 9.2 (95\% confidence interval: 3.41-25.21)]. In the multivariate logistic regression analysis, when the variables below the $p<0.20$ value shown in Table 2 (age, basal phosphorus, ferritin, 25-OH Vit D, PTH levels and FCM doses) were evaluated, only the basal phosphorus level $(p<0,01)$ and FCM dose $(p<0.05)$ were statistically significant (Table 3 ).

Treatment-related pruritus developed in 3 patients (3.2\%), myalgia in 2 patients $(2.1 \%)$, subfebrile fever in 2 patients $(2.1 \%)$, and nausea in 1 patient $(1 \%)$. However, it was not necessary to discontinue the drug due to these side effects. Anaphylaxis and injection site complications were not observed in any of the patients.

Table 1. Comparison of laboratory characteristics before and after ferric carboxymaltose treatment

\begin{tabular}{|c|c|c|c|}
\hline & Before FCM & After FCM & $p$ value \\
\hline $\mathrm{Hb}(\mathrm{gr} / \mathrm{dL})$ & $9.99 \pm 1.25$ & $11.83 \pm 1.05$ & ${ }^{\dagger}<0.000^{* *}$ \\
\hline Htc (\%) & $31.69 \pm 3.36$ & $36.64 \pm 2.74$ & ${ }^{\dagger}<0.000^{* *}$ \\
\hline Ferritin (ng/mL) & $5.60(3.7-10.0)$ & $128.2(34.7-291)$ & ${ }^{\ddagger}<0.000^{* *}$ \\
\hline Phosphorus (mg/dL) & $3.34 \pm 0.39$ & $2.22 \pm 0.57$ & ${ }^{\dagger}<0.000^{* *}$ \\
\hline $25-\mathrm{OH}$ Vit D (ng/mL) & $13.25(8.3-21.0)$ & $14.5(4.2-84.5)$ & ${ }^{\ddagger} 0.414$ \\
\hline PTH (pg/mL) & $73.3 \pm 23.24(21.9-157)$ & $76 \pm 24.16(17.9-153.9)$ & ${ }^{+} 0.09$ \\
\hline
\end{tabular}


Table 2. Comparison of groups developing and not developing hypophosphatemia

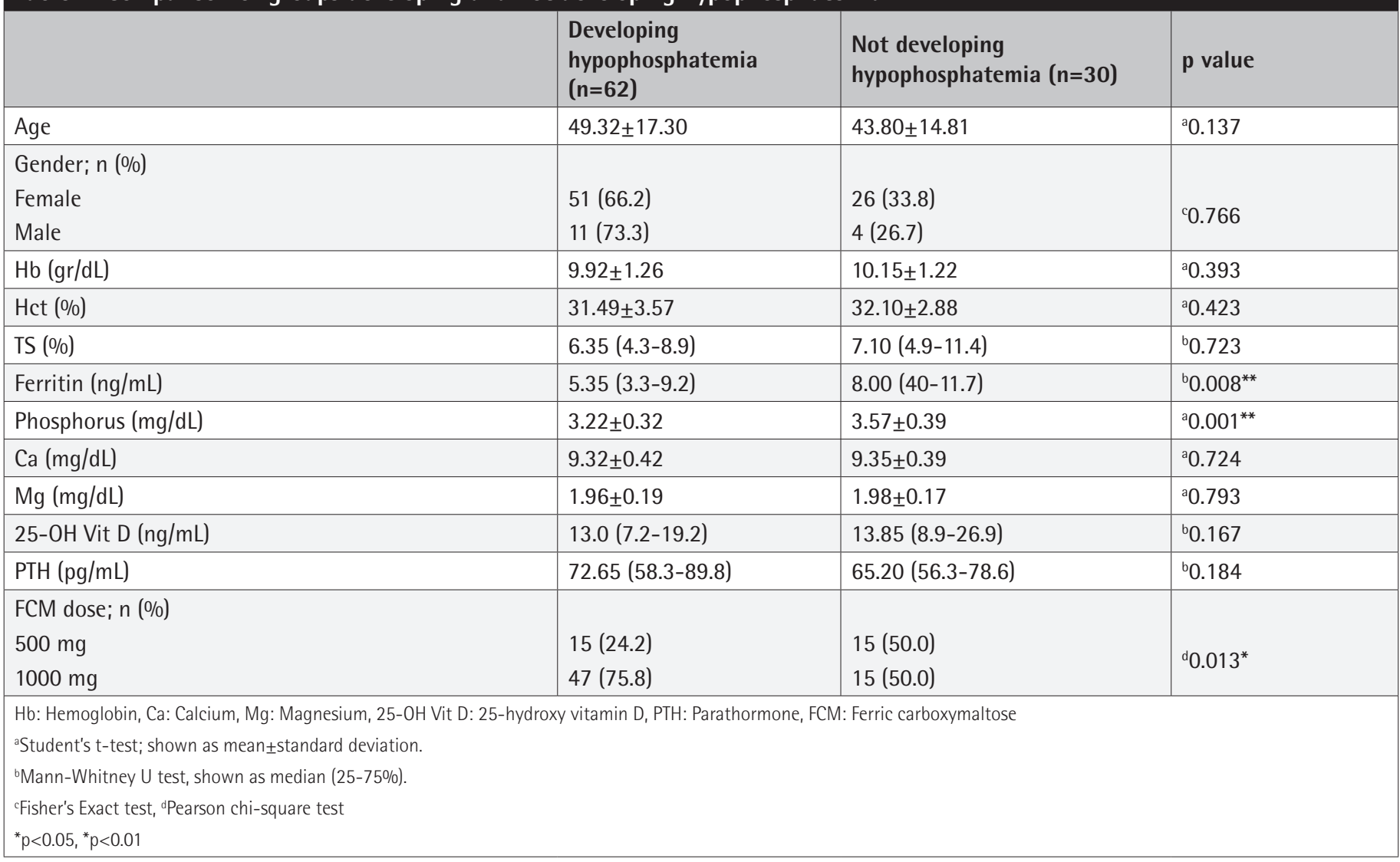

Table 3. Logistic regression analysis of risk factors affecting hypophosphatemia

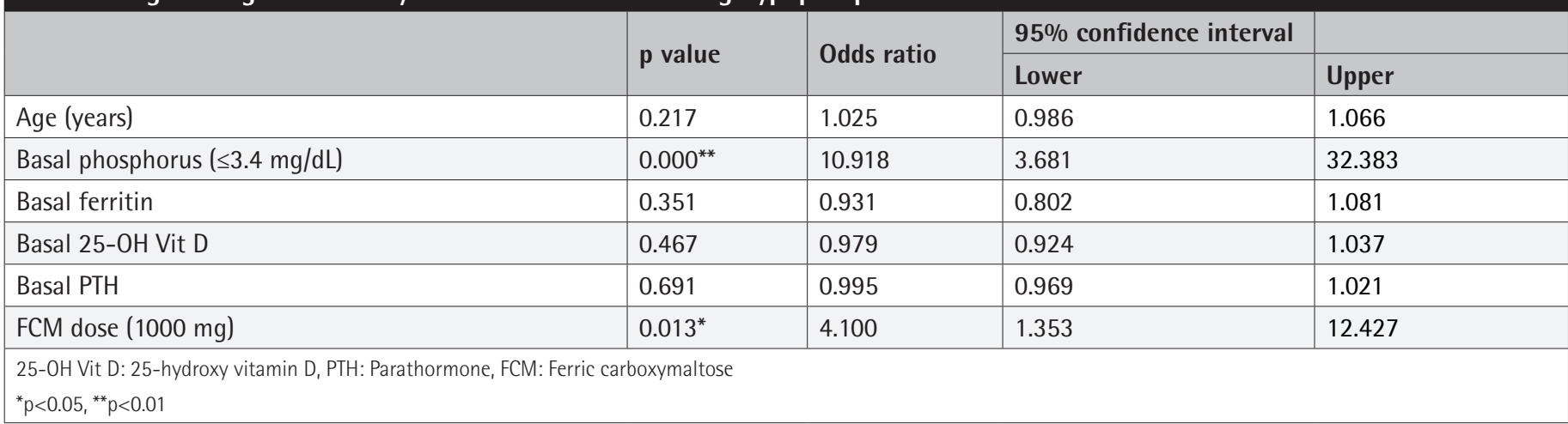

\section{DISCUSSION}

IDA is a public health problem that mostly occurs in children, premenopausal women and pregnant women ${ }^{1}$. Oral or parenteral iron preparations are used in the treatment of IDA. Discontinuation of oral therapy due to gastrointestinal side effects and the patient's inability to use the drug regularly and for a sufficient time are common ${ }^{4}$. Apart from intolerance to oral iron therapy, parenteral iron therapy should be preferred in inflammatory bowel diseases, absorption disorders such as gastrectomy, and functional iron deficiency (chronic kidney failure, inflammatory diseases, malignancies) ${ }^{12}$. FCM is a new generation parenteral iron preparation. It is administered over a short infusion time of 20-30 minutes and can be given in a single dose of $1000 \mathrm{mg}$. It has high stability due to its high molecular weight. This makes the side effects of labile iron less common in FCM. Thanks to its neutral $\mathrm{pH}$ and physiological osmolarity, complications such as discoloration, extravasation and pain at the injection site are less common. Due to the low immunogenicity of FCM, anaphylactic reactions are extremely rare $^{5}$. Side effects such as nausea, injection site reactions, headache, hypertension, dizziness, vomiting and diarrhea are similar in FCM and other parenteral iron preparations. The rate of severe anaphylactic reaction in FCM is between 0.1\% and $0.9 \% 0^{13}$. In our study, mild side effects that did not require discontinuation of treatment were observed in 8 patients after FCM. Application site complications and anaphylaxis did not 
occur in any of the patients. Due to these advantages, FCM has been shown to be effective in many conditions such as chronic kidney failure, heart failure, postpartum period, pregnancy, and chronic gastrointestinal bleeding in recent years ${ }^{5}$.

Hypophosphatemia due to iv iron therapy is a known side effect. This rate is higher in FCM and the duration of hypophosphatemia is longer. In the literature, the incidence of hypophosphatemia was found to be $0-92.1 \%$ in FCM, $0-40 \%$ in iron sucrose, $0.4 \%$ in ferumoxytol, and $0 \%$ in low molecular weight iron dextran, and hypophosphatemia was generally defined as asymptomatic ${ }^{14}$. In the study by Emrich et al. ${ }^{6}$, phosphorus values of the patients receiving FCM and iron isomaltozide (IIM) were compared on the $1^{\text {st }}, 7^{\text {th }}$ and $35^{\text {th }}$ days. The incidence of hypophosphatemia $(\mathrm{p}<2 \mathrm{mg} / \mathrm{dL})$ was $75 \%$ in FCM and $8 \%$ in IIM $(p<0.001)$. The lowest phosphorus value was seen on the $7 \pm 2^{\text {th }}$ days and it was observed that the decrease in phosphorus levels continued on the $35^{\text {th }}$ day in patients who received FCM. No change was observed in calcium, PTH, alkaline phosphatase and 25-OH Vit D levels in both groups. In DCM, serum intact FGF-23 (iFGF-23) levels were found to be higher on the first day $(p<0.001)$. In the study conducted by Wolf et al. ${ }^{8}$, serum phosphorus levels of patients receiving FCM and ferumoxytol were evaluated at the $1^{\text {st }}, 2^{\text {nd }}$ and $5^{\text {th }}$ weeks of treatment, and the rate of hypophosphatemia was higher in FCM patients $(50.8 \%$ vs $0.9 \%)(p<0.001)$ and similarly, the incidence of severe hypophosphatemia $(<1.3 \mathrm{mg} / \mathrm{dL})$ was found to be higher $(10 \%$ vs $0 \%)(p<0.001)$. At the end of the fifth week, phosphorus levels of all patients who received ferumoxytol returned to normal, while it was reported that hypophosphatemia continued in $29.1 \%$ of those who received FCM $(p<0.001)$. It has been stated that the increase in serum iFGF-23 levels is held responsible for hypophosphatemia.

The incidence of hypophosphatemia in our study was consistent with the literature (67.4\%). Severe hypophosphatemia was seen in only 2 patients (2.1\%), and this rate was lower than in the literature. This situation may be related to the fact that our study is retrospective so we can evaluate serum phosphorus levels only between 10-14 days. If we had a chance to see serum phosphorus values earlier after treatment, we might have a higher probability of detecting severe hypophosphatemia. In our study, the incidence of hypophosphatemia was higher in those treated with $1000 \mathrm{mg} \mathrm{FCM}$, and we found that basal phosphorus level and FCM dose were independent risk factors for hypophosphatemia. No study comparing $500 \mathrm{mg}$ and 1000 mg FCM doses was found in the literature. However, while hypophosphatemia was found in $26.9 \%$ in those receiving $750 \mathrm{mg}$ DCM in studies, this rate was reported as $50.8 \%$ in those receiving $1000 \mathrm{mg}^{7,13}$. In a study comparing cumulative doses, hypophosphatemia was found at a higher rate in those who received $2090 \mathrm{mg}$ FCM compared to those who received $1350 \mathrm{mg}$ on average $(p=0.04)^{15}$. The cut-off value of hypophosphatemia and the day of evaluation of serum phosphorus level were specified differently in each study. There is still no standard consensus on whether routine phosphorus levels should be checked in patients undergoing FCM, and if it will be checked on which days after treatment.

FGF-23 is a secretory protein ligand produced mainly by osteoblasts and osteocytes. Only iFGF-23 is biologically active. The C-terminal part of iFGF-23 is cleaved by the proteolytic pathway and becomes inactive. FGF-23 suppresses non-tissuespecific alkaline phosphatase under physiological conditions. It increases urinary phosphate excretion and inhibits phosphate reabsorption. The resulting hypophosphatemia causes inhibition of bone mineralization.

FGF-23, phosphate involved in mineral metabolism and vitamin D are stimulated by PTH. In addition, there is an increase in serum levels in cases of iron deficiency and the release of proinflammatory cytokines ${ }^{16}$. Total serum FGF-23 level is inversely proportional to serum iron concentration in patients without renal dysfunction. Although total FGF23 levels increase in iron deficiency, iFGF-23 level is usually within normal limits. This is because the stabilizing state of post-translational FGF-23 cleavage ensures that iFGF-23 levels remain normal despite an increase in C-terminal FGF-23 levels. Therefore, hypophosphatemia is not usually seen in IDA ${ }^{17}$. In case of iron deficiency, while FGF-23 transcription increases, iFGF-23 remains within normal limits. When iron dextran is used in treatment, the increase in FGF-23 transcription returns to normal. Increased C-terminal FGF-23 levels normalize, while iFGF-23 levels remain unchanged. When FCM is used, the transcription of FGF-23 regresses to normal, while the production of iFGF-23 protein increases. Although the mechanism of this is not known exactly, it is thought that the carbohydrate sheath of FCM causes the increase of iFGF-23 by inhibiting the proteolytic cleavage of FGF-23. This increase causes hypophosphatemia ${ }^{13}$. The difference in the incidence of hypophosphatemia between FCM and other iv iron preparations is explained by this hypothesis.

Although hypophosphatemia related to FCM has been defined as mostly asymptomatic in randomized controlled studies, cases with severe hypophosphatemia, cramps, dizziness, fatigue, nausea, and requiring long-term hospitalization have been reported in the acute period ${ }^{14,15,18}$. In addition, hypophosphatemic osteomalacia and related fractures have been reported in patients receiving repeated doses of therapy in recent years. In these patients, monthly FCM infusion was administered for two years ${ }^{19,20}$. It has been stated that the risk of osteomalacia and fractures may increase after FCM, especially in those who receive frequent FCM treatment, malnutrition, 25-OH Vit D deficiency, osteoporosis, hyperparathyroidism, and patients with low basal calcium and phosphorus levels ${ }^{20}$. 


\section{Study Limitations}

The limitation of our study is that it is a retrospective study. Therefore, phosphorus levels were only obtained in the range of 10-14 days after FCM treatment. However, the incidence of hypophosphatemia was found to be consistent with the literature.

\section{CONCLUSION}

In conclusion, FCM is frequently used in our daily practice for the treatment of IDA. Although its advantages provide us convenience, the incidence and duration of hypophosphatemia is longer than other iv iron preparations. Mostly, hypophosphatemia is asymptomatic. Currently, routine serum phosphorus monitoring is not recommended. However, it has been reported that osteomalacia and fractures due to hypophosphatemia can be seen in the use of FCM at high and frequently repeated doses. Particular attention should be paid to hypophosphatemia in cases with low basal phosphorus levels and high doses of FCM treatment. For this reason, it should be kept in mind to monitor the phosphorus level in risky patients.

\section{Ethics}

Ethics Committee Approval: Ethics committee approval was obtained by the Üniversity of Health Sicences Turkey, Kocaeli Derince Training and Research Hospital Clinical Research Ethics Committee with the protocol number 2020/82 dated 25.06.2020.

Informed Consent: Retrospective study.

Peer-review: Externally peer-reviewed.

Financial Disclosure: The author declared that this study received no financial support.

\section{References}

1. World Health Organization. Iron Deficiency Anaemia Assessment, Prevention, and Control. A guide for programme managers. Switzerland: World Health Organization; 2001.

2. World Health Organization. The global prevalence of anaemia in 2011. Geneva: World Health Organization; 2015.

3. Cancelo-Hidalgo MJ, Castelo-Branco C, Palacios S, Haya-Palazuelos J, Ciria-Recasens M, Manasanch J, et al. Tolerability of different oral iron supplements: a systematic review. Curr Med Res Opin. 2013;29:291-303.
4. Gereklioglu C, Asma S, Korur A, Erdogan F, Kut A. Medication adherence to oral iron therapy in patients with iron deficiency anemia. Pak J Med Sci. 2016;32:604-7.

5. Qunibi WY. The efficacy and safety of current intravenous iron preparations for the management of iron-deficiency anaemia: a review. Arzneimittelforschung. 2010;60:399-412.

6. Emrich IE, Lizzi F, Siegel JD, Seiler-Mussler S, Ukena C, Kaddu-Mulindwa D, et al. Hypophosphatemia after high-dose iron repletion with ferric carboxymaltose and ferric derisomaltose-the randomized controlled HOMe aFers study. BMC Med. 2020;18:178.

7. Wolf M, Rubin J, Achebe M, Econs MJ, Peacock M, Imel EA, et al. Effects of Iron Isomaltoside vs Ferric Carboxymaltose on Hypophosphatemia in IronDeficiency Anemia: Two Randomized Clinical Trials. JAMA. 2020;323:43243.

8. Wolf M, Chertow GM, Macdougall IC, Kaper R, Krop J, Strauss W. Randomized trial of intravenous iron-induced hypophosphatemia. JCl Insight. 2018;3:e124486.

9. World Health Organization, Worldwide Prevalance of Anemia 19932005. WHO Global Database on Anaemia. Switzerland: World Health Organization; 2008.

10. Short MW, Domagalski JE. Iron deficiency anemia: evaluation and management. Am Fam Physician. 2013;87:98-104.

11. World Health Organization, International statistical classification of diseases and related health problems. - 10th revision, World Health Organization Geneva, Switzerland: 2016.

12. Cançado RD, Muñoz M. Intravenous iron therapy: how far have we come? Rev Bras Hematol Hemoter. 2011;33:461-9.

13. Bregman DB, Goodnough LT. Experience with intravenous ferric carboxymaltose in patients with iron deficiency anemia. Ther Adv Hematol. 2014;5:48-60.

14. Glaspy JA, Lim-Watson MZ, Libre MA, Karkare SS, Hadker N, Bajic-Lucas A, et al. Hypophosphatemia Associated with Intravenous Iron Therapies for Iron Deficiency Anemia: A Systematic Literature Review. Ther Clin Risk Manag. 2020;16:245-59.

15. Hardy $S$, Vandemergel $X$. Intravenous iron administration and hypophosphatemia in clinical practice. Int J Rheumatol. 2015;2015:468675.

16. Hanudel MR, Laster M, Salusky IB. Non-renal-Related Mechanisms of FGF23 Pathophysiology. Curr Osteoporos Rep. 2018;16:724-9.

17. Imel EA, Liu Z, McQueen AK, Acton D, Acton A, Padgett LR, et al. Serum fibroblast growth factor 23 , serum iron and bone mineral density in premenopausal women. Bone. 2016;86:98-105.

18. Ifie E, Oyibo SO, Joshi H, Akintade O. Symptomatic hypophosphataemia after intravenous iron therapy: an underrated adverse reaction. Endocrinol Diabetes Metab Case Rep. 2019;2019:19-0065.

19. Callejas-Moraga EL, Casado E, Gomez-Nuñez M, Caresia-Aroztegui AP. Severe osteomalacia with multiple insufficiency fractures secondary to intravenous iron therapy in a patient with Rendu-Osler-Weber syndrome. Bone Rep. 2020;13:100712.

20. Fang $W$, McMahon $L P$, Bloom $S$, Garg M. Symptomatic severe hypophosphatemia after intravenous ferric carboxymaltose. JGH Open. 2019;3:438-40. 